\title{
Effects of weight change on apolipoprotein B-containing emerging atherosclerotic cardiovascular disease (ASCVD) risk factors
}

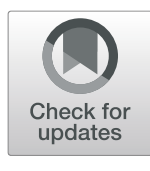

Michael L. Dansinger ${ }^{1,2^{*}}$, Paul T. Williams ${ }^{1} \mathbb{D}$, H. Robert Superko ${ }^{1}$ and Ernst J. Schaefer ${ }^{1,3}$

\begin{abstract}
Background and aims: Non-high-density (HDL)-cholesterol, low-density lipoprotein (LDL)-particle number, apolipoprotein B, lipoprotein(a) (Lp(a)), and small-dense (sdLDL) and large-buoyant (IbLDL) LDL-subfractions are emerging apo B-containing atherosclerotic cardiovascular disease (ASCVD) risk factors. Current guidelines emphasize lifestyle, including weight loss, for ASCVD risk management. Whether weight change affects these emerging risk factors beyond that predicted by traditional triglyceride and LDL-cholesterol measurements remains to be determined.
\end{abstract}

Method: Regression analyses of fasting $\triangle a p o$ B-containing lipoproteins vs. $\triangle B M I$ were examined in a large anonymized clinical laboratory database of 33,165 subjects who did not report use of lipid-lowering medications. Regression slopes ( \pm SE) were estimated as: ${ }^{*} \Delta \mathrm{mmol} / \mathrm{L}$ per $\Delta \mathrm{kg} / \mathrm{m}^{2},{ }^{\dagger} \Delta \mathrm{g} / \mathrm{L}$ per $\Delta \mathrm{kg} / \mathrm{m}^{2},{ }^{\ddagger} \Delta \%$ per $\Delta \mathrm{kg} / \mathrm{m}^{2}$, and ${ }^{\S} \Delta \mu \mathrm{mol} / \mathrm{L} \mathrm{per} \Delta \mathrm{kg} / \mathrm{m}^{2}$.

Results: When adjusted for age, $\triangle B M I$ was significantly related to $\Delta$ nonHDL-cholesterol (males: $0.0238 \pm 0.0041$, $P=7.9 \times 10^{-9}$; females: $\left.0.0330 \pm 0.0037, P<10^{-16}\right)^{*}, \Delta$ LDL-particles (males: $0.0128 \pm 0.0024, P=2.1 \times 10^{-7}$; females: $\left.0.0114 \pm 0.0022, P=3.2 \times 10^{-7}\right)^{*}, \triangle$ apo B (males: $0.0053 \pm 0.0010, P=7.9 \times 10^{-8}$; females: $0.0073 \pm$ $\left.0.0009, P=2.2 \times 10^{-16}\right)^{\dagger}, \Delta s d L D L$ (males: $0.0125 \pm 0.0015, P=2.2 \times 10^{-16}$; females: $\left.0.0128 \pm 0.0012, P<10^{-16}\right)^{*}$, $\triangle$ percent LDL carried on small dense particles (\%sdLDL, males: $0.296 \pm 0.035, P<10^{-16}$; females: $0.221 \pm 0.023$, $\left.P<10^{-16}\right)^{\ddagger}, \Delta$ triglycerides (males: $0.0358 \pm 0.0049, P=2.0 \times 10^{-13}$; females: $\left.0.0304 \pm 0.0029, P<10^{-16}\right)^{*}$, and $\triangle L D L$-cholesterol (males: $0.0128 \pm 0.0034, P=0.0002$; females: $0.0232 \pm 0.0031, P=1.2 \times 10^{-13}$ ) in both males and females. Age-adjusted $\triangle B M I$ was significantly related to $\triangle \mathrm{lbLDL}$ in females $\left(0.0098 \pm 0.0024, P=3.9 \times 10^{-5}\right)^{*}$ but not males $(0.0007 \pm 0.0026, P=0.78)^{*}$. Female showed significantly greater increases in $\triangle \mathrm{LDL}$-cholesterol $(P=0.02)$ and $\triangle \mathrm{lbLDL}(P=0.008)$ per $\triangle \mathrm{BMl}$ than males. $\triangle \mathrm{BMI}$ had a greater effect on $\triangle \mathrm{LDL}$-cholesterol measured directly than indirect estimate of $\Delta L D L$-cholesterol from the Friedewald equation. When sexes were combined and adjusted for age, sex, $\triangle$ triglycerides and $\triangle \mathrm{LDL}$-cholesterol, $\triangle B M I$ retained residual associations with $\triangle$ nonHDL-cholesterol $(0.0019 \pm 0.0009, P=0.03)^{*}, \Delta$ LDL-particles $(0.0032 \pm 0.0010, P=0.001)^{*}, \Delta$ apo B $(0.0010 \pm 0.0003, P=0.0008)^{\dagger}, \Delta \operatorname{Lp}(\mathrm{a})\left(-0.0091 \pm 0.0021, P=1.2 \times 10^{-5}\right)^{\S}, \Delta \mathrm{sdLDL}\left(0.0001 \pm 0.0000, P=1.6 \times 10^{-}\right.$ $\left.{ }^{11}\right)^{*}$ and $\triangle \%$ sdLDL $\left(0.151 \pm 0.018, P<10^{-16}\right)^{\ddagger}$.

Conclusions: Emerging apo B-containing risk factors show associations with weight change beyond those explained by the more traditional triglyceride and LDL-cholesterol measurements.

Keywords: Cholesterol, Triglyceides, Low-density lipoproteins, Apolipoprotein B, lipoprotein(a), Weight loss, Obesity

\footnotetext{
* Correspondence: mdansinger@bostonheartdx.com

${ }^{1}$ Boston Heart Diagnostics, 175 Crossing Boulevard, Suite 100, Framingham,

MA 01702, USA

${ }^{2}$ Tufts Medical Center, 800 Washington St, Boston, MA 02111, USA

Full list of author information is available at the end of the article
}

(c) The Author(s). 2019 Open Access This article is distributed under the terms of the Creative Commons Attribution 4.0 International License (http://creativecommons.org/licenses/by/4.0/), which permits unrestricted use, distribution, and reproduction in any medium, provided you give appropriate credit to the original author(s) and the source, provide a link to the Creative Commons license, and indicate if changes were made. The Creative Commons Public Domain Dedication waiver (http://creativecommons.org/publicdomain/zero/1.0/) applies to the data made available in this article, unless otherwise stated. 


\section{Background}

Lipoprotein management has historically focused on indirect low-density lipoprotein (LDL) and triglyceride concentrations [1]. However, many individuals develop ischemic heart disease despite having had indirect LDLcholesterols within the normal range [1, 2]. Indirect LDL-cholesterol values are calculated using the Friedewald equation [3], which is subject to inaccuracy in the presence of high triglycerides and other conditions [4]. More recently, the desire for greater accuracy has lead to the development of direct measurements of LDLcholesterol [4]. Triglycerides are not thought to be atherosclerotic per se, but reflect high cholesterol concentrations in triglyceride-rich lipoproteins, and influence the metabolism of other lipoproteins more directly involved in the atherogenic process [1]. Current treatment guidelines do not target triglycerides concentrations under $500 \mathrm{mg} / \mathrm{dL}[1,5]$.

Several emerging apolipoprotein (apo)-B containing risk factors have been identified due to their stronger relationships to atherosclerotic cardiovascular disease (ASCVD) risk than LDL-cholesterol, or their residual risk after adjusting for LDL-cholesterol and triglycerides. Non-high density lipoprotein (HDL) cholesterol provides a single global index of cholesterol in all apoB containing atherogenic lipoproteins, including very-low-density lipoprotein (VLDL) and triglyceride-rich remnant lipoproteins [5]. Prospectively, non-HDL-cholesterol has been shown to be superior to LDL-cholesterol in predicting increased CHD risk $[6,7]$, and in predicting CHD risk independent of LDL-cholesterol [8]. In clinical trials, on-study nonHDLcholesterol was a better predictor of CVD-risk than LDLcholesterol in the treating to new targets (TNT) and Incremental Decrease in End Points Through Aggressive Lipid Lowering (IDEAL) trials [9], and was closely associated with coronary atheroma progression irrespective of on-study LDL-cholesterol [10]. It has been identified as a secondary target when triglycerides $\geq 200 \mathrm{mg} / \mathrm{dL}$ [1].

Apolipoprotein (apo) B concentrations measure total LDL, intermediate density lipoproteins (IDL), very low density lipoproteins (VLDL), and lipoprotein(a) (Lp(a)) particle concentrations because each particle contains exactly one apoB100 molecule [1]. Prospectively, it has been shown to improve risk prediction for cardiovascular events after controlling for traditional risk factors [11]. Clinical trials show that on-study apo B concentrations were better predictors of CVD-risk than LDLcholesterol [9]. Apo B concentrations of $<90 \mathrm{mg} / \mathrm{dL}$ (< 80 in very high risk patients) is the target goal proposed as by National Lipid Association in patients treated for cholesterol [2].

ASCVD is thought to be more a function of the total number of apo B containing particles than LDL-cholesterol, which is not a reliable estimate of LDL particle number.
LDL-particle concentrations show a stronger association with future CVD risk than either LDL-cholesterol or non HDL-cholesterol, and in the case of discordant LDLparticle and LDL-concentrations, CVD risk tracks with LDL-particle and not LDL-cholesterol [12, 13]. Finally, we note that LDL is made up of multiple particles subclasses that differ by size, density and composition [14]. Smallerdenser LDL particles measured by their cholesterol concentration (sdLDL) or as a percentage of the total LDLcholesterol (\%sdLDL) have been associated with increased ASCVD risk, whereas there is much less evidence linking larger buoyant LDL (lbLDL) to increased risk [15].

Weight loss and other lifestyle modifications play a major role in managing dyslipidemia [16]. A three-kg weight loss reduces triglyceride concentrations by at least $0.17 \mathrm{mmol} / \mathrm{L}$ ( $15 \mathrm{mg} / \mathrm{dL}$ ), and a 5 - to 8 - $\mathrm{kg}$ weight loss produces a $0.13 \mathrm{mmol} / \mathrm{L}(5-\mathrm{mg} / \mathrm{dL})$ average LDL-cholesterol reduction [16]. There is a manifest need to identify the effects of weight loss on emerging ASCVD risk factors, and to assess whether they differs from their expected effects given their associations with triglycerides and LDLcholesterol. To this end, we analyzed the relationships between changes $(\Delta)$ in clinically reported weight and $\Delta$ plasma concentrations of apo B-containing risk factors in a national anonymized clinical laboratory database. The relationships of $\Delta$ plasma $\mathrm{HDL}$-subclass concentrations and $\triangle \mathrm{BMI}$ have been previously reported [17].

\section{Methods}

Epidemiological analyses of the large clinical laboratory datasets have been previously used in the study of the effects of health policy [18], environmental impact [19], temporal trends [20, 21], lipoproteins [22, 23], and other blood components [24] on health biomarkers. There were 67,210 women and 57,375 men not on lipid-lowering medications whose physicians provided clinical BMI measurements and sent fasting blood samples to Boston Heart Diagnostics for laboratory analysis between December 16, 2010 and October 31, 2017. Age, gender, height, weight, and use of lipid-lowering medications were obtained from the sample submission form. Laboratory assays of the blood draws were made at the time of the blood draws for total cholesterol (enzymatic colorimetric), triglycerides (enzymatic colorimetric), low-density lipoprotein (LDL)-cholesterol (direct, enzymatic colorimetric), and HDL-cholesterol (enzymatic colorimetric). All analyses were performed on anonymized data collected in a large clinical laboratory and are exempt from human subjects. The dataset has been previously reported in our studies of changes in weight vs. HDL-subfractions [17] and temporal changes in LDLcholesterol concentrations following the promotion of 
the treat-to-risk guidelines for cholesterol management [25].

Indirect LDL-cholesterol was obtained from the Friedewald equation: total cholesterol - triglycerides $/ 5$ for triglycerides $\leq 400 \mathrm{mg} / \mathrm{dL}$ and direct LDL-cholesterol for triglycerides $>400$. [3] Direct LDL-cholesterol and sdLDLcholesterol were measured using automated standardized enzymatic analysis on a Hitachi 911 automated analyzer and kits provided by the Denka Seiken Corporation, Tokyo, Japan. Specifically, we incubated plasma $(0.1 \mathrm{ml})$ combined with $0.1 \mathrm{ml}$ precipitation reagent containing heparin sodium salt and $\mathrm{MgCl}$ for $10 \mathrm{~min}$ at $37^{\circ} \mathrm{C}$. sdLDL-C was then measured by the homogenous method after separation of the sdLDL fraction $(\mathrm{d}=1.044-1.063 \mathrm{~g} /$ $\mathrm{ml}$ ) and HDL by filtration [26-29]. Large buoyant LDL (lbLDL)-cholesterol values were calculated as difference between direct LDL-cholesterol - sdLDL-cholesterol. The percentage of total LDL-cholesterol carried on the small dense LDL (\%sdLDL-cholesterol) was calculated as 100*sdLDL-cholesterol/total LDL-cholesterol. Lp(a) levels using the Denka Seiken latex-enhanced turbidimetric immunoassay. LDL-particle concentrations were determined by nuclear magnetic resonance (NMR), and apo B concentrations by immunoturbidimetric method.

\section{Statistical analyses}

Statistical analyses of the anonymized data were performed using the JMP statistical package for the Macintosh (version 13, SAS institute, Cary, NC). Results are presented as means (standard deviations) and slopes \pm SE. Subjects who reported the use of cholesterollowering medications were excluded. Age-adjustment was achieved using sex-specific second-order polynomial of age and age ${ }^{2}$. Results are presented in Système international (SI) units with the conventional units provided as Additional file 1. The first follow-up visit is considered the primary due to its substantially larger sample size than the second and third follow-up visits.

\section{Results}

At baseline, the men averaged 58.4 (13.7) and the women 58.1 (14.0) years of age. Their baseline body weight distribution were: $0.3 \%$ of men and $1.4 \%$ of women were underweight $\left(\mathrm{BMI}<18.5 \mathrm{~kg} / \mathrm{m}^{2}\right), 17.6 \%$ of men and $32.5 \%$ of women were healthy weight $(18.5 \leq$ BMI $\left.<25 \mathrm{~kg} / \mathrm{m}^{2}\right) ; 41.4 \%$ of men and $30.4 \%$ of women were overweight $\left(25 \leq \mathrm{BMI}<30 \mathrm{~kg} / \mathrm{m}^{2}\right) ; 25.9 \%$ of men and $18.8 \%$ of women were class I obese $(30 \leq \mathrm{BMI}<35$ $\left.\mathrm{kg} / \mathrm{m}^{2}\right) ; 9.6 \%$ of men and $9.7 \%$ of women were class II obese $\left(35 \leq \mathrm{BMI}<40 \mathrm{~kg} / \mathrm{m}^{2}\right)$; and $5.1 \%$ of men and $7.2 \%$ of women were class III obese (BMI $\left.>40 \mathrm{~kg} / \mathrm{m}^{2}\right)$. The first, second, and third follow-up visits averaged 0.8, 1.4, and 1.8 years after baseline, respectively. The men lost an average of $-0.12(2.02) \mathrm{kg} / \mathrm{m}^{2}$ by the first follow-up,
$-0.21(2.13) \mathrm{kg} / \mathrm{m}^{2}$ by the second follow-up, and -0.22 (2.36) $\mathrm{kg} / \mathrm{m}^{2}$ by the third follow-up survey. The corresponding losses for women were-0.10 (2.01), -0.14 (2.28), and $-0.15(2.60) \mathrm{kg} / \mathrm{m}^{2}$. Table 1 presents the sample's baseline lipoprotein characteristics, and the average lipoprotein changes between the first, second and third follow-up visits.

The age-adjusted regression analyses of Table 2 show the concordant relationships of $\Delta \mathrm{BMI}$ vs. $\Delta$ triglycerides, $\Delta$ apo B, $\Delta$ nonHDL-cholesterol, $\Delta \%$ sdLDL-cholesterol, and $\Delta$ LDL-particle number all were highly significant, a finding replicated in both men and women. Weight change was inversely related to $\Delta \mathrm{Lp}(\mathrm{a})$ and weakly or unrelated to $\triangle \mathrm{lbLDL}$-cholesterol. The regression slopes for $\Delta \mathrm{LDL}$-cholesterol vs. $\triangle \mathrm{BMI}$ were greater for the direct measurement than the calculated estimates of LDLcholesterol. The effects of $\triangle \mathrm{BMI}$ on $\triangle \mathrm{LDL}$-cholesterol and $\triangle \mathrm{lbLDL}$-cholesterol were generally less in men than women, whereas the effect of $\triangle \mathrm{BMI}$ on $\Delta \mathrm{Lp}(\mathrm{a})$ was greater in men.

Table 3 tests whether the aforementioned associations can be simply attributed to $\Delta$ triglycerides and $\Delta$ LDL-cholesterol. When sexes were combined and adjusted for age, sex, $\Delta$ triglycerides and $\Delta \mathrm{LDL}$-cholesterol, $\Delta \mathrm{BMI}$ : 1 ) gained a strongly significant inverse relationship with $\triangle$ lbLDL, 2) retained the all of its significant residual association with $\Delta \mathrm{Lp}(\mathrm{a})$ and the majority of its association with $\Delta \% \mathrm{sdLDL}$ cholesterol, and 3) maintained significant but much reduced associations with $\Delta$ apo $B, \Delta$ nonHDL-cholesterol, $\Delta$ LDL-particles, and $\Delta$ sdLDL-cholesterol. The analyses were repeated separately in males and females for $\triangle$ lbLDL-cholesterol due to its significant sex differences of Table 2. In males and females separately, $\triangle B M I$ was significantly associated with both $\triangle \mathrm{lbLDL}$-cholesterol (males: $-0.0047 \pm 0.0009, \quad P=3.6 \times 10^{-7} ;$ females: $-0.0038 \pm$ $0.0007 \Delta \mathrm{mmol} / \mathrm{L}$ per $\Delta \mathrm{kg} / \mathrm{m}^{2}, P=3.4 \times 10^{-8}$ ) when adjusted. Similar results were obtained when the preceding analyses used $\Delta \log$ triglycerides rather than $\Delta$ triglycerides as a covariate (analyses not displayed).

\section{Discussion}

These analyses examine the associations between $\Delta B M I$ and $\triangle \mathrm{apoB}$ containing lipoproteins before and after adjustment for $\Delta$ triglycerides and $\Delta \mathrm{LDL}$-cholesterol. This was done to assess whether these emerging risk factors provide additional information on the benefits and hazards of body weight vis-á-vis traditional lipid measurements. Table 2 showed that $\triangle B M I$ had a stronger effect (larger regression slope) on $\triangle \mathrm{LDL}$-cholesterol measured directly than on $\Delta \mathrm{LDL}$-cholesterol estimated indirectly by the Friedewald equation. Although the Friedewald estimates were strongly correlated with the direct measurement $(r=0.98)$, they are reported to underestimate the direct measurement by about $5 \%$ with increasing 
Table 1 Baseline characteristics and mean changes from baseline, SI units

\begin{tabular}{|c|c|c|c|c|}
\hline & \multirow{3}{*}{$\begin{array}{l}\text { Baseline } \\
\text { Mean (SD) }\end{array}$} & \multicolumn{3}{|c|}{ Difference from baseline ${ }^{e}$} \\
\hline & & \multicolumn{3}{|c|}{ Mean difference \pm SE } \\
\hline & & 1st follow-up & 2nd follow-up & 3rd follow-up \\
\hline \multicolumn{5}{|l|}{ Males } \\
\hline Triglycerides $^{a}$ & $1.623(1.330)$ & $-0.100 \pm 0.010$ & $-0.107 \pm 0.016$ & $-0.132 \pm 0.027$ \\
\hline Log triglycerides & $0.273(0.544)$ & $-0.054 \pm 0.003$ & $-0.058 \pm 0.006$ & $-0.075 \pm 0.009$ \\
\hline Apo $B^{b}$ & $0.961(0.287)$ & $-0.045 \pm 0.002$ & $-0.049 \pm 0.004$ & $-0.054 \pm 0.006$ \\
\hline Non-HDL-cholesterol ${ }^{a}$ & $3.502(1.171)$ & $-0.237 \pm 0.009$ & $-0.278 \pm 0.015$ & $-0.321 \pm 0.022$ \\
\hline LDL-cholesterol direct ${ }^{a}$ & $2.975(1.033)$ & $-0.18 \pm 0.007$ & $-0.21 \pm 0.012$ & $-0.251 \pm 0.019$ \\
\hline LDL-cholesterol indirect $^{a}$ & $2.797(1.024)$ & $-0.188 \pm 0.007$ & $-0.234 \pm 0.013$ & $-0.273 \pm 0.018$ \\
\hline sdLDL-cholesterol ${ }^{\mathrm{a}}$ & $0.808(0.45)$ & $-0.064 \pm 0.003$ & $-0.074 \pm 0.005$ & $-0.08 \pm 0.008$ \\
\hline |bLDL-cholesterol $^{\mathrm{a}}$ & $2.17(0.777)$ & $-0.114 \pm 0.005$ & $-0.139 \pm 0.01$ & $-0.167 \pm 0.014$ \\
\hline \%sdLDL-cholesterol ${ }^{\mathrm{c}}$ & $23.23(7.82)$ & $-0.38 \pm 0.07$ & $-0.43 \pm 0.13$ & $-0.31 \pm 0.20$ \\
\hline LDL-particles $^{a}$ & $1.322(0.528)$ & $-0.070 \pm 0.005$ & $-0.069 \pm 0.009$ & $-0.095 \pm 0.013$ \\
\hline $\operatorname{Lp}(a)^{d}$ & $5.192(0.955)$ & $-0.037 \pm 0.006$ & $-0.041 \pm 0.01$ & $-0.042 \pm 0.015$ \\
\hline $\log \operatorname{Lp}(a)$ & $1.636(0.183)$ & $-0.008 \pm 0.001$ & $-0.010 \pm 0.002$ & $-0.011 \pm 0.003$ \\
\hline \multicolumn{5}{|l|}{ Females } \\
\hline Triglycerides $^{a}$ & $1.402(0.923)$ & $-0.052 \pm 0.006$ & $-0.072 \pm 0.012$ & $-0.07 \pm 0.013$ \\
\hline Log triglycerides & $0.273(0.544)$ & $-0.033 \pm 0.003$ & $-0.045 \pm 0.005$ & $-0.050 \pm 0.007$ \\
\hline$A p o B^{b}$ & $0.987(0.281)$ & $-0.029 \pm 0.002$ & $-0.036 \pm 0.003$ & $-0.038 \pm 0.006$ \\
\hline Non-HDL-cholesterol ${ }^{a}$ & $3.63(1.127)$ & $-0.167 \pm 0.007$ & $-0.229 \pm 0.014$ & $-0.27 \pm 0.024$ \\
\hline LDL-cholesterol direct ${ }^{a}$ & $3.177(1.023)$ & $-0.133 \pm 0.006$ & $-0.174 \pm 0.012$ & $-0.212 \pm 0.02$ \\
\hline LDL-cholesterol indirect $^{a}$ & $3.006(1.019)$ & $-0.152 \pm 0.006$ & $-0.208 \pm 0.012$ & $-0.256 \pm 0.02$ \\
\hline sdLDL-cholesterol ${ }^{a}$ & $0.754(0.393)$ & $-0.042 \pm 0.002$ & $-0.05 \pm 0.004$ & $-0.05 \pm 0.007$ \\
\hline |bLDL-cholesterol ${ }^{\mathrm{a}}$ & $2.426(0.781)$ & $-0.091 \pm 0.005$ & $-0.124 \pm 0.009$ & $-0.156 \pm 0.015$ \\
\hline \%sdLDL-cholesterol ${ }^{\mathrm{c}}$ & $0.714(0.27)$ & $-0.16 \pm 0.05$ & $-0.01 \pm 0.08$ & $0.19 \pm 0.14$ \\
\hline LDL-particles $^{a}$ & $1.350(0.513)$ & $-0.048 \pm 0.004$ & $-0.066 \pm 0.008$ & $-0.076 \pm 0.013$ \\
\hline$L p(a)^{d}$ & $6.145(1.178)$ & $-0.050 \pm 0.006$ & $-0.047 \pm 0.011$ & $-0.05 \pm 0.017$ \\
\hline $\log \operatorname{Lp}(a)$ & $1.803(0.191)$ & $-0.008 \pm 0.001$ & $-0.010 \pm 0.002$ & $-0.011 \pm 0.003$ \\
\hline
\end{tabular}

inaccuracy with increasing triglyceride concentrations [4]. In addition, body weight change was associated with significant changes in apoB, nonHDL-cholesterol, LDLparticle, sdLDL-cholesterol, \%sdLDL-cholesterol concentrations, and Lp(a) but not lbLDL-concentrations concentrations. The associations were unaffected by sex for $\Delta$ triglycerides, $\Delta$ apoB, $\Delta$ nonHDL-cholesterol, and $\Delta \mathrm{LDL}-$ particle concentrations, were somewhat stronger in women than men for $\triangle \mathrm{LDL}$-cholesterol and $\triangle \mathrm{lbLDL}-$ cholesterol, and stronger in men than women for $\Delta \mathrm{Lp}(\mathrm{a})$.

The effects of weight loss on LDL are well established. Meta-analyses of weight loss studies estimate that a 16 $\mathrm{kg}$ or $16 \%$ average weight loss produces a $0.78 \mathrm{mmol} / \mathrm{L}$ $(30 \mathrm{mg} / \mathrm{dL})$ average reduction in total cholesterol due to equal reductions in LDL-cholesterol and VLDLcholesterol, and an average LDL-cholesterol reduction of $0.021 \mathrm{mmol} / \mathrm{L}(0.8 \mathrm{mg} / \mathrm{dL})$ per $\mathrm{kg}$ lost [30]. Equal effects on LDL- and VLDL-cholesterol support the use of nonHDL-cholesterol in the analysis of weight loss. Meta-analyses have also shown significant reductions in apo $\mathrm{B}$ concentrations in hypoenergic diets producing 6$12 \%$ weight loss [31]. Tables 2 and 3 showed that $\Delta$ apo B, $\Delta$ nonHDL-cholesterol, $\triangle$ LDL-particles, and $\Delta \%$ sdLDL all showed significantly stronger (i.e, more significant) relationships to $\triangle \mathrm{BMI}$ than the traditional $\triangle \mathrm{LDL}$-cholesterol concentrations, suggesting potentially even greater health benefits of weight management. Their relationships with $\triangle B M I$ remained significant when adjusted for $\Delta$ triglycerides and $\Delta$ LDL-cholesterol.

As expected, $\Delta$ triglycerides and $\Delta$ LDL-cholesterol were concordantly related with $\triangle \mathrm{BMI}$. High triglyceride levels associated with abdominal obesity are due to enhanced secretion (accounting for $20 \%$ of plasma triglyceride concentrations) and impaired clearance of 
Table 2 Regression analyses of age-adjusted $\triangle$ apoB-containing lipoproteins vs. $\triangle B M I$ over clinic visits. SI units

\begin{tabular}{|c|c|c|c|c|c|c|}
\hline \multirow{2}{*}{$\begin{array}{l}\text { Dependent } \\
\text { variable }\end{array}$} & \multicolumn{2}{|l|}{ Male } & \multicolumn{2}{|l|}{ Female } & \multirow{2}{*}{$\begin{array}{l}\text { Sex dif- } \\
\text { ference } \\
\text { (P) }\end{array}$} & \multirow{2}{*}{$\begin{array}{l}\text { Sample (N) } \\
\text { Male/female }\end{array}$} \\
\hline & Slope \pm SE & Signif-icance & Slope \pm SE & Signi-ficance & & \\
\hline \multicolumn{7}{|l|}{$\Delta$ Triglycerides $^{\mathrm{a}}$} \\
\hline 1st followup & $0.0358 \pm 0.0049$ & $2.0 \times 10^{-13}$ & $0.0304 \pm 0.0029$ & $<10^{-16}$ & 0.33 & $14690 / 17977$ \\
\hline 2nd followup & $0.0308 \pm 0.0076$ & $5.1 \times 10^{-5}$ & $0.033 \pm 0.0053$ & $3.4 \times 10^{-10}$ & 0.77 & $5109 / 5893$ \\
\hline 3rd followup & $0.0147 \pm 0.0115$ & 0.20 & $0.0315 \pm 0.005$ & $3.0 \times 10^{-10}$ & 0.16 & $2334 / 2372$ \\
\hline \multicolumn{7}{|l|}{$\Delta$ Log triglycerides } \\
\hline 1st followup & $0.019 \pm 0.002$ & $<10^{-16}$ & $0.019 \pm 0.001$ & $<10^{-16}$ & 0.96 & 14690/17977 \\
\hline 2nd followup & $0.024 \pm 0.003$ & $<10^{-16}$ & $0.025 \pm 0.002$ & $<10^{-16}$ & 0.89 & $5109 / 5893$ \\
\hline 3rd followup & $0.020 \pm 0.004$ & $7.9 \times 10^{-8}$ & $0.022 \pm 0.003$ & $2.7 \times 10^{-15}$ & 0.57 & $2334 / 2372$ \\
\hline \multicolumn{7}{|l|}{$\triangle A p o B^{b}$} \\
\hline 1st followup & $0.0053 \pm 0.0010$ & $7.9 \times 10^{-8}$ & $0.0073 \pm 0.0009$ & $2.2 \times 10^{-16}$ & 0.12 & $13384 / 16458$ \\
\hline 2nd followup & $0.005 \pm 0.0017$ & 0.003 & $0.0072 \pm 0.0015$ & $9.6 \times 10^{-7}$ & 0.29 & $4483 / 5231$ \\
\hline 3rd followup & $0.0075 \pm 0.0028$ & 0.007 & $0.0067 \pm 0.0023$ & 0.003 & 0.85 & 1925/1973 \\
\hline \multicolumn{7}{|c|}{$\Delta$ nonHDL-cholesterol ${ }^{a}$} \\
\hline 1st followup & $0.0238 \pm 0.0041$ & $7.9 \times 10^{-9}$ & $0.0330 \pm 0.0037$ & $<10^{-16}$ & 0.07 & $12471 / 15149$ \\
\hline 2nd followup & $0.0254 \pm 0.0068$ & 0.0002 & $0.0282 \pm 0.0059$ & $2.0 \times 10^{-6}$ & 0.72 & $4323 / 4860$ \\
\hline 3rd followup & $0.0235 \pm 0.0089$ & 0.008 & $0.0267 \pm 0.009$ & 0.003 & 0.81 & 1974/1979 \\
\hline \multicolumn{7}{|c|}{$\Delta \mathrm{LDL}$-cholesterol direct $\mathrm{t}^{\mathrm{a}}$} \\
\hline 1st followup & $0.0128 \pm 0.0034$ & 0.0002 & $0.0232 \pm 0.0031$ & $1.2 \times 10^{-13}$ & 0.02 & $14349 / 17625$ \\
\hline 2nd followup & $0.0093 \pm 0.0058$ & 0.11 & $0.0202 \pm 0.0051$ & $7.5 \times 10^{-5}$ & 0.14 & $4985 / 5792$ \\
\hline 3rd followup & $0.0134 \pm 0.0078$ & 0.09 & $0.0235 \pm 0.0075$ & 0.002 & 0.34 & $2287 / 2331$ \\
\hline \multicolumn{7}{|c|}{$\Delta \mathrm{LDL}$-cholesterol indirect ${ }^{\mathrm{a}}$} \\
\hline 1st followup & $0.0084 \pm 0.0034$ & 0.01 & $0.0186 \pm 0.0031$ & $1.6 \times 10^{-9}$ & 0.02 & $14238 / 17455$ \\
\hline 2nd followup & $0.0048 \pm 0.0059$ & 0.41 & $0.0134 \pm 0.0051$ & 0.008 & 0.22 & $4954 / 5700$ \\
\hline 3rd followup & $0.0139 \pm 0.0077$ & 0.07 & $0.0198 \pm 0.0076$ & 0.009 & 0.56 & $2282 / 2307$ \\
\hline \multicolumn{7}{|c|}{$\Delta$ sdLDL-cholesterol ${ }^{a}$} \\
\hline 1st followup & $0.0125 \pm 0.0015$ & $2.2 \times 10^{-16}$ & $0.0128 \pm 0.0012$ & $<10^{-16}$ & 0.85 & $13668 / 16875$ \\
\hline 2nd followup & $0.0109 \pm 0.0025$ & $8.2 \times 10^{-6}$ & $0.0144 \pm 0.0019$ & $8.4 \times 10^{-15}$ & 0.21 & $4721 / 5524$ \\
\hline 3rd followup & $0.0121 \pm 0.0033$ & 0.0003 & $0.0123 \pm 0.0027$ & $4.6 \times 10^{-6}$ & 0.92 & $2185 / 2235$ \\
\hline \multicolumn{7}{|c|}{$\Delta \mathrm{bLDL}$-cholesterol ${ }^{\mathrm{a}}$} \\
\hline 1st followup & $0.0007 \pm 0.0026$ & 0.78 & $0.0098 \pm 0.0024$ & $3.9 \times 10^{-5}$ & 0.008 & $13518 / 16727$ \\
\hline 2nd followup & $-0.0005 \pm 0.0044$ & 0.90 & $0.0055 \pm 0.0039$ & 0.16 & 0.27 & $4680 / 5475$ \\
\hline 3rd followup & $0.0021 \pm 0.0059$ & 0.72 & $0.0114 \pm 0.0057$ & 0.05 & 0.25 & $2174 / 2210$ \\
\hline \multicolumn{7}{|c|}{$\Delta \%$ sdLDL-cholesterol $^{c}$} \\
\hline 1st followup & $0.296 \pm 0.035$ & $<10^{-16}$ & $0.221 \pm 0.023$ & $<10^{-16}$ & 0.06 & $10605 / 13757$ \\
\hline 2nd followup & $0.294 \pm 0.06$ & $8.2 \times 10^{-7}$ & $0.259 \pm 0.038$ & $6.4 \times 10^{-12}$ & 0.63 & $3429 / 4229$ \\
\hline 3rd followup & $0.389 \pm 0.098$ & $6.9 \times 10^{-5}$ & $0.196 \pm 0.056$ & 0.0004 & 0.07 & $1438 / 1522$ \\
\hline \multicolumn{7}{|c|}{$\Delta L D L$-particle number ${ }^{a}$} \\
\hline 1st followup & $0.0128 \pm 0.0024$ & $2.1 \times 10^{-7}$ & $0.0114 \pm 0.0022$ & $3.2 \times 10^{-7}$ & 0.69 & $7408 / 9025$ \\
\hline 2nd followup & $0.0100 \pm 0.0036$ & 0.005 & $0.0109 \pm 0.0034$ & 0.002 & 0.81 & $2600 / 3004$ \\
\hline 3rd followup & $0.0122 \pm 0.0046$ & 0.008 & $0.0117 \pm 0.0048$ & 0.02 & 0.92 & $1177 / 1289$ \\
\hline \multicolumn{7}{|l|}{$\Delta L \mathrm{p}(\mathrm{a})^{\mathrm{d}}$} \\
\hline 1st followup & $-0.0206 \pm 0.0064$ & 0.001 & $-0.0010 \pm 0.0030$ & 0.75 & 0.009 & $13126 / 16094$ \\
\hline 2nd followup & $-0.0257 \pm 0.0087$ & 0.003 & $-0.0121 \pm 0.0047$ & 0.01 & 0.15 & $4587 / 5277$ \\
\hline
\end{tabular}




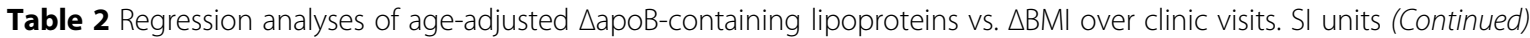

\begin{tabular}{|c|c|c|c|c|c|c|}
\hline \multirow{2}{*}{$\begin{array}{l}\text { Dependent } \\
\text { variable }\end{array}$} & \multicolumn{2}{|l|}{ Male } & \multicolumn{2}{|l|}{ Female } & \multirow{2}{*}{$\begin{array}{l}\text { Sex dif- } \\
\text { ference } \\
\text { (P) }\end{array}$} & \multirow{2}{*}{$\begin{array}{l}\text { Sample }(\mathrm{N}) \\
\text { Male/female }\end{array}$} \\
\hline & Slope \pm SE & Signif-icance & Slope \pm SE & Signi-ficance & & \\
\hline 3rd followup & $-0.029 \pm 0.0094$ & 0.002 & $-0.0092 \pm 0.0064$ & 0.15 & 0.19 & $2138 / 2169$ \\
\hline \multicolumn{7}{|l|}{$\Delta \log \operatorname{Lp}(\mathrm{a})^{d}$} \\
\hline 1st followup & $-0.002 \pm 0.001$ & $4.7 \times 10^{-5}$ & $0.000 \pm 0.000$ & 0.94 & 0.003 & $13113 / 16077$ \\
\hline 2nd followup & $-0.004 \pm 0.001$ & $8.6 \times 10^{-6}$ & $-0.002 \pm 0.001$ & 0.02 & 0.06 & $4586 / 5273$ \\
\hline 3rd followup & $-0.004 \pm 0.001$ & 0.004 & $-0.002 \pm 0.001$ & 0.11 & 0.20 & 2138/2169 \\
\hline
\end{tabular}

triglyceride-rich lipoproteins (accounting for 50\%) [32]. Total body fat and liver fat content largely determine the amount of triglyceride secreted by the liver, mostly in the form of large triglyceride rich VLDL1 particles, but also VLDL2. The VLDLtriglycerides are hydrolyzed by lipoprotein lipase on the on the luminal surfaces of muscle and adipose tissue, releasing fatty acids for energy production or storage. The impaired clearance is largely due to increased levels of apo C-III, an inhibitor of hepatic and lipoprotein lipase that also impairs VLDL clearance by interfering with the binding of $a p o B$ and apoE to hepatic receptors [32-34].

Unlike other apo B-containing lipoproteins, changes in Lp(a) were inversely related to BMI change, particularly in men, and the association was somewhat strengthened when adjusted for changes in triglycerides and LDLcholesterol. Their inverse relationship has been noted by others [35-37], and although other studies report little effect of weight loss on $\operatorname{Lp}(\mathrm{a})$ concentrations [38], they involve substantially fewer subjects than reported here.

\section{LDL-subclasses}

Historically, LDL heterogeneity were categorized in terms of the relative concentrations of large and small LDL as phenotypes A (preponderance of large LDL) and phenotype B (preponderance of small LDL) or the LDLpeak particle diameter (estimated diameter of the mean or mode of LDL particle distribution) [14], which corresponds most closely with the \%sdLDL of the present analyses. This parameterization is most appropriate for metabolic processes that alter the equilibrium distribution of large and small LDL, e.g., if body weight increases triglycerides concentrations, which in turn shifts the precursor-product relationship from lbLDL (1.044$1.063 \mathrm{~g} / \mathrm{ml}$ density) to sdLDL (1.019-1.043 g/ml density) due to increased cholesteryl ester triglyceride exchange, then adjustment for $\Delta$ triglyceride concentrations should mostly eliminate the association between $\triangle B M I$ and $\Delta \%$ sdLDL, which was not observed. In fact, Table 3 suggests the majority of the effect of $\triangle \mathrm{BMI}$ on $\Delta \%$ sdLDL was independent of triglycerides and LDL-cholesterol concentrations. This agrees with compartmental models that exclude the possibility of sdLDL being produced exclusively from the delipidation of lbLDL [39].

At least some of the concordance between $\Delta$ sdLDL and $\triangle B M I$ was attributable to $\Delta$ triglycerides, albeit not the majority. sdLDL particles are derived from multiple sources, providing multiple pathways by which $\Delta$ weightmediated $\Delta$ triglycerides could affect $\Delta$ sdLDL concentrations. Some sdLDL is derived directly from VLDL and IDL independently of lbLDL, some from the delipidation of lbLDL, and some secreted directly by the liver [39]. High triglycerides concentrations are associated with greater hepatic secretion of sdLDL particles than lbLDL particles, a greater number of VLDL particles being converted to sdLDL density than catabolized, a greater fraction of lbLDL delipidated to sdLDL, and slow clearance of sdLDL due to its greater apo CIII content [40].

The lack of concordance between $\triangle \mathrm{lbLDL}$ and $\triangle \mathrm{BMI}$ may be due to two counterbalancing effects of triglyceride enrich lipoproteins: lower concentrations resulting in reduced cholesteryl ester-triglyceride exchange (an lbLDL increasing effect) and reduced availability of lbLDL-precursors (an lbLDL decreasing effect), while higher concentrations having the opposite consequences. Specifically, lower plasma triglyceride concentration with weight loss may limit the cholesteryl ester transfer protein (CETP)-mediated exchange of VLDL-triglycerides for LDL-cholesteryl esters leading to an accumulation of lbLDL-cholesterol in parallel with increasing HDLcholesterol concentrations [39]. The CETP-inhibitor torcetrapib has been shown to produce parallel increases large LDL and HDL-cholesterol [41]. Fewer available precursors and less exchange may result in no net lbLDL increase.

Differences in the metabolic regulation of sdLDL and lbLDL are also presumed to explain the LDL-cholesterol differences for weight loss by traditional low-fat diets vs. high fat ketogenic diets. Both reduce plasma concentrations of small dense LDL. However, weight loss achieved by very-low-carbohydrate ketogenic diets significantly increase LDL-cholesterol and decreased triglycerides in association with weight loss compared to a traditional low-fat diet $(4.6 \mathrm{mg} / \mathrm{dL}$ greater LDL-cholesterol increase and $15.9 \mathrm{mg} / \mathrm{dL}$ greater triglyceride decrease for $0.91 \mathrm{~kg}$ 


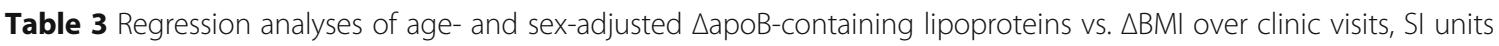

\begin{tabular}{|c|c|c|c|c|c|}
\hline \multirow[b]{2}{*}{ Dependent variable } & \multicolumn{2}{|c|}{ Adjusted for age and sex only } & \multicolumn{2}{|c|}{ Additional adjustment for $\Delta$ triglycerides and $\Delta \mathrm{LDL}$-cholesterol } & \multirow[t]{2}{*}{ Sample (N) } \\
\hline & Slope \pm SE & $\overline{\text { Significance }}$ & Slope \pm SE & Significance & \\
\hline \multicolumn{6}{|l|}{$\triangle \mathrm{Apo} \mathrm{B}$} \\
\hline 1st followup & $0.0064 \pm 0.0007$ & $<10^{-16}$ & $0.001 \pm 0.0003$ & 0.0008 & 29342 \\
\hline 2nd followup & $0.0063 \pm 0.0011$ & $1.9 \times 10^{-8}$ & $0.0016 \pm 0.0005$ & 0.0006 & 9642 \\
\hline 3rd followup & $0.007 \pm 0.0017$ & $5.8 \times 10^{-5}$ & $0.001 \pm 0.0007$ & 0.16 & 3877 \\
\hline \multicolumn{6}{|c|}{$\Delta$ nonHDL-cholesterol ${ }^{\text {a }}$} \\
\hline 1st followup & $0.0289 \pm 0.0027$ & $<10^{-16}$ & $0.0019 \pm 0.0009$ & 0.03 & 27613 \\
\hline 2nd followup & $0.027 \pm 0.0045$ & $1.5 \times 10^{-9}$ & $0.0058 \pm 0.0015$ & 0.0001 & 9180 \\
\hline 3rd followup & $0.0252 \pm 0.0063$ & $6.8 \times 10^{-5}$ & $0.0088 \pm 0.0022$ & $6.3 \times 10^{-5}$ & 3952 \\
\hline \multicolumn{6}{|l|}{$\Delta$ sdLDL-cholesterol ${ }^{a}$} \\
\hline 1st followup & $0.0008 \pm 0.0001$ & $<10^{-16}$ & $0.0001 \pm 0.0000$ & $1.6 \times 10^{-11}$ & 29988 \\
\hline 2nd followup & $0.0007 \pm 0.0001$ & $<10^{-16}$ & $0.0002 \pm 0.0001$ & $1.5 \times 10^{-11}$ & 10164 \\
\hline 3rd followup & $0.0006 \pm 0.0002$ & $6.6 \times 10^{-9}$ & $0.0002 \pm 0.0001$ & 0.0003 & 4396 \\
\hline \multicolumn{6}{|l|}{$\Delta \mathrm{lbLDL-cholesterol}{ }^{\mathrm{a}}$} \\
\hline 1st followup & $0.0059 \pm 0.0018$ & 0.0009 & $-0.0041 \pm 0.0006$ & $3.4 \times 10^{-13}$ & 30056 \\
\hline 2nd followup & $0.0029 \pm 0.0029$ & 0.33 & $-0.0059 \pm 0.0009$ & $3.8 \times 10^{-11}$ & 10124 \\
\hline 3rd followup & $0.0073 \pm 0.0041$ & 0.08 & $-0.0052 \pm 0.0012$ & $3.2 \times 10^{-15}$ & 4376 \\
\hline \multicolumn{6}{|l|}{$\Delta \%$ sdLDL-cholesterol ${ }^{c}$} \\
\hline 1st followup & $0.254 \pm 0.02$ & $<10^{-16}$ & $0.151 \pm 0.018$ & $<10^{-16}$ & 24274 \\
\hline 2nd followup & $0.274 \pm 0.034$ & $4.4 \times 10^{-16}$ & $0.186 \pm 0.03$ & $3.8 \times 10^{-10}$ & 7633 \\
\hline 3rd followup & $0.27 \pm 0.053$ & $2.9 \times 10^{-7}$ & $0.218 \pm 0.049$ & $8.2 \times 10^{-6}$ & 2952 \\
\hline \multicolumn{6}{|c|}{$\Delta \mathrm{LDL}$-particle number ${ }^{\mathrm{a}}$} \\
\hline 1st followup & $0.0121 \pm 0.0017$ & $2.9 \times 10^{-13}$ & $0.0032 \pm 0.0010$ & 0.001 & 16135 \\
\hline 2nd followup & $0.0105 \pm 0.0025$ & $2.6 \times 10^{-5}$ & $0.0039 \pm 0.0015$ & 0.01 & 5554 \\
\hline 3rd followup & $0.0119 \pm 0.0033$ & 0.0003 & $0.0037 \pm 0.0022$ & 0.10 & 2452 \\
\hline \multicolumn{6}{|l|}{$\Delta L p(a)^{d}$} \\
\hline 1st followup & $-0.0059 \pm 0.0021$ & 0.005 & $-0.0091 \pm 0.0021$ & $1.2 \times 10^{-5}$ & 28096 \\
\hline 2nd followup & $-0.0163 \pm 0.0033$ & $7.8 \times 10^{-7}$ & $-0.018 \pm 0.0033$ & $5.3 \times 10^{-8}$ & 9673 \\
\hline 3rd followup & $-0.0142 \pm 0.0045$ & 0.002 & $-0.0155 \pm 0.0045$ & 0.0006 & 4264 \\
\hline \multicolumn{6}{|l|}{$\Delta \log \operatorname{Lp}(\mathrm{a})$} \\
\hline 1st followup & $-0.001 \pm 0$ & 0.005 & $-0.002 \pm 0$ & $9.0 \times 10^{-6}$ & 28096 \\
\hline 2nd followup & $-0.003 \pm 0.001$ & $2.9 \times 10^{-6}$ & $-0.003 \pm 0.001$ & $2.2 \times 10^{-7}$ & 9673 \\
\hline 3rd followup & $-0.003 \pm 0.001$ & 0.002 & $-0.003 \pm 0.001$ & 0.0006 & 4264 \\
\hline \multicolumn{6}{|l|}{$\Delta$ Triglycerides $^{\mathrm{a}}$} \\
\hline 1st followup & $0.0328 \pm 0.0027$ & $<10^{-16}$ & & & 32674 \\
\hline 2nd followup & $0.032 \pm 0.0045$ & $7.5 \times 10^{-13}$ & & & 11001 \\
\hline 3rd followup & $0.0241 \pm 0.006$ & $6.1 \times 10^{-5}$ & & & 4706 \\
\hline \multicolumn{6}{|l|}{$\Delta \mathrm{LDL}$-cholesterol ${ }^{\mathrm{a}}$} \\
\hline 1st followup & $0.0186 \pm 0.0023$ & $6.7 \times 10^{-16}$ & & & 31981 \\
\hline 2nd followup & $0.0155 \pm 0.0038$ & $5.3 \times 10^{-5}$ & & & 10776 \\
\hline 3rd followup & $0.019 \pm 0.0054$ & 0.0004 & & & 4618 \\
\hline
\end{tabular}

${ }^{a} \Delta \mathrm{mmol} / \mathrm{L}$ per $\Delta \mathrm{kg} / \mathrm{m}^{2} ;{ }^{\mathrm{b}} \Delta \mathrm{g} / \mathrm{L}$ per $\Delta \mathrm{kg} / \mathrm{m}^{2} ;{ }^{\mathrm{c}} \Delta \%$ per $\Delta \mathrm{kg} / \mathrm{m}^{2} ;{ }^{\mathrm{d}} \Delta \mu \mathrm{mol} / \mathrm{L}$ per $\Delta \mathrm{kg} / \mathrm{m}^{2}$ 
greater average weight loss) [42]. This presumably relates to the higher saturated fat intake of ketogenic diets, which is estimated to increase LDL-cholesterol by 0.8 to $1.6 \mathrm{mg} / \mathrm{dL}$ for each $1 \%$ increase in energy from saturated fat [43]. Increased saturated fat intake is reported to affect the larger more buoyant LDL in the context of limiting carbohydrate intake [44].

In addition to identifying differences in their metabolic regulation, the subclass specific associations between $\triangle B M I$ and $\triangle$ LDL-cholesterol are important because sdLDL and lbLDL show very different associations with CVD risk [45]. Compared to sdLDL, lbLDL are less readily oxidized in vitro [46], have less affinity proteoglycans in the arterial wall [47], contain a lower percentage of glycated apo B [48], and are overall less susceptible to glycation [49]. Prospective cohort and case-control studies show greater ASCVD risk for sdLDL and not lbLDL $[15,50,51]$, although as in the case of its BMI association, the increased ASCVD risk of sdLDL is not necessarily independent of plasma triglycerides.

\section{Caveats and limitations}

An important strength of this large clinical database analysis is the opportunity to assess the magnitude of weightrelated changes in a variety of atherogenic lipoprotein particles in the context of actual clinical practice. However, although the population generally reflects the outpatient primary care population of thousands of diverse medical practices, it is not feasible to precisely define the clinical characteristics of the specific study population. Important examples include the lack of more-extensive information on lifestyle (such as dietary intake, physical activity, or causes of weight change), medical treatment (such as medications) and general health status. This limits the ability to statistically adjust for different causes of weight change, which could potentially modify the statistical relationship between changes in weight and various atherogenic particles. To avoid confounding by the presence or absence of lipid-lowering medication use, we excluded individuals known to take such medications. Nevertheless, in some cases the absence of lipid-lowering medications may have been due to nonresponse. Waist circumference, an index of intra-abdominal fat that likely has a more direct relationship to altered lipoprotein metabolism in the obese state [52], was not available. The associations reported here do not prove causality, although the causal relationship between weight loss and apoB-containing lipoproteins is firmly established by others [30, 31]. The sample was not obtained under any predefined sampling strategy. However, the sample is likely not atypical of the conditions encountered under usual practice and therefore provide realistic expectations of the improvement or decline associated with changing weight in the clinical setting. Whereas most prior reports on LDL-subfractions in relation to weight loss are from small studies, the over 30 , 000 subjects reported here provides precise estimates for LDL-subfractions known to be important for their difference in metabolism, functionality, and cardiovascular disease risk.

\section{Conclusion}

The emerging apo B-containing risk factors examined in this report show associations with weight change beyond those explained by the more-traditional measurements of triglyceride and LDL-cholesterol.

\section{Additional file}

Additional file 1: Supplemental Data File. (DOCX $82 \mathrm{~kb}$ )

\section{Abbreviations}

\%sdLDL: percent of LDL-cholesterol carried on small dense low-density lipoproteins; BMl: Body mass index; HDL: High density lipoproteins; IbLDL: Large buoyant low-density lipoproteins; LDL: Low-density lipoproteins;

Lp(a): Lipoprotein(a); sdLDL: small dense low-density lipoproteins; VLDL: Very low density lipoproteins

\section{Acknowledgements}

Not applicable.

Authors' contributions

MD, PTW, HRS, and EJS all contributed substantially to the conception, writing and critical review of the manuscript. PTW was additionally involved with the statistical analysis, and takes responsibility for its accuracy. All authors read and approved the final manuscript.

\section{Funding}

This research was funded by Boston Heart Diagnostics, Framingham MA.

Availability of data and materials

The datasets analyzed in this report may be available from the corresponding author on reasonable request.

Ethics approval and consent to participate

All analyses were performed on anonymized data collected in a large clinical laboratory and are exempt from human subjects.

Consent for publication

Not applicable

\section{Competing interests}

Michael Dansinger, Paul Williams, H Robert Superko, and Ernst J. Schaefer all receive financial support as employees or consultants for Boston Heart Diagnostics, Inc., which could benefit financially from cholesterol testing.

\section{Author details}

${ }^{1}$ Boston Heart Diagnostics, 175 Crossing Boulevard, Suite 100, Framingham, MA 01702, USA. ${ }^{2}$ Tufts Medical Center, 800 Washington St, Boston, MA 02111, USA. ${ }^{3}$ Cardiovascular Nutrition Laboratory, USDA Human Nutrition Research Center at Tufts University, 711 Washington St., Boston, MA 02111, USA.

Received: 8 January 2019 Accepted: 1 July 2019

Published online: 17 July 2019

References

1. National Cholesterol Education Program (NCEP). Expert panel on detection, evaluation, and treatment of high blood cholesterol in adults (adult treatment panel III), third report of the National Cholesterol Education Program (NCEP) expert panel on detection, evaluation, and treatment of 
high blood cholesterol in adults (adult treatment panel III) final report. Circulation. 2002;106:3143-421.

2. Jacobson TA, Ito MK, Maki KC, Orringer CE, Bays HE, Jones PH, McKenney JM, Grundy SM, Gill EA, Wild RA, Wilson DP, Brown WW. National lipid association recommendations for patient-centered management of dyslipidemia: part 1_full report. J Clin Lipidol. 2015;9:129-69.

3. Friedewald WT, Levy RI, Fredrickson DS. Estimation of the concentration of low-density lipoprotein cholesterol in plasma, without use of the preparative ultracentrifuge. Clin Chem. 1972;18:499-502.

4. Schaefer EJ, Tsunoda F, Diffenderfer M, et al. The Measurement of Lipids, Lipoproteins, Apolipoproteins, Fatty Acids, and Sterols, and Next Generation Sequencing for the Diagnosis and Treatment of Lipid Disorders. [Updated 2016 Mar 29]. In: Feingold KR, Anawalt B, Boyce A, et al., editors. Endotext [Internet]. South Dartmouth (MA): MDText.com, Inc.; 2000-. Available from https://www.ncbi.nlm.nih.gov/books/NBK355892/?report=reader.

5. Stone NJ, Robinson JG, Lichtenstein AH, Bairey Merz CN, Blum CB, Eckel RH, Goldberg AC, Gordon D, Levy D, Lloyd-Jones DM, McBride P, Schwartz JS, Shero ST, Smith SC Jr, Watson K, Wilson PW, Eddleman KM, Jarrett NM, LaBresh K, Nevo L, Wnek J, Anderson JL, Halperin JL, Albert NM, Bozkurt B, Brindis RG, Curtis LH, DeMets D, Hochman JS, Kovacs RJ, Ohman EM, Pressler SJ, Sellke FW, Shen WK, Smith SC Jr, Tomaselli GF. American College of Cardiology/American Heart Association task force on practice guidelines. 2013 ACC/AHA guideline on the treatment of blood cholesterol to reduce atherosclerotic cardiovascular risk in adults: a report of the American College of Cardiology/American Heart Association task force on practice guidelines. Circulation. 2014;129(25 Suppl 2):S1-45.

6. Ridker PM, Rifai N, Cook NR, Bradwin G, Buring JE. Non-HDL cholesterol, apolipoproteins A-I and B100, standard lipid measures, lipid ratios, and CRP as risk factors for cardiovascular disease in women. JAMA. 2005; 294:326-33.

7. Pischon T, Girman CJ, Sacks FM, Rifai N, Stampfer MJ, Rimm EB. Non-highdensity lipoprotein cholesterol and apolipoprotein B in the prediction of coronary heart disease in men. Circulation. 2005;112:3375-83.

8. Arsenault BJ, Rana JS, Stroes ES, Després JP, Shah PK, Kastelein JJ, Wareham NJ, Boekholdt SM, Khaw KT. Beyond low-density lipoprotein cholesterol: respective contributions of non-high-density lipoprotein cholesterol levels, triglycerides, and the total cholesterol/high-density lipoprotein cholesterol ratio to coronary heart disease risk in apparently healthy men and women. J Am Coll Cardiol. 2009:55:35-41.

9. Kastelein JJ, van der Steeg WA, Holme I, Gaffney M, Cater NB, Barter P, Deedwania P, Olsson AG, Boekholdt SM, Demicco DA, Szarek M, LaRosa JC, Pedersen TR, Grundy SM. TNT study group; IDEAL study group. Lipids, apolipoproteins, and their ratios in relation to cardiovascular events with statin treatment. Circulation. 2008;117:3002-9.

10. Puri R, Nissen SE, Shao M, Elshazly MB, Kataoka Y, Kapadia SR, Tuzcu EM, Nicholls SJ. Non-HDL cholesterol and triglycerides: implications for coronary atheroma progression and clinical events. Arterioscler Thromb Vasc Biol. 2016;36:2220-8.

11. Wilkins JT, Li RC, Sniderman A, Chan C, Lloyd-Jones DM. Discordance between apolipoprotein $B$ and LDL-cholesterol in young adults predicts coronary artery calcification: The CARDIA Study. J Am Coll Cardiol. 2016;67: 193-201.

12. Otvos JD, Mora S, Shalaurova I, Greenland P, Mackey RH, Goff DC Jr. Clinical implications of discordance between low-density lipoprotein cholesterol and particle number. J Clin Lipidol. 2011;5:105-13.

13. Parish S, Offer A, Clarke R, Hopewell JC, Hill MR, Otvos JD, Armitage J, Collins R. Heart protection study collaborative group. Lipids and lipoproteins and risk of different vascular events in the MRC/BHF heart protection study. Circulation. 2012;125:2469-78.

14. Krauss RM, Burke DJ. Identification of multiple subclasses of plasma low density lipoproteins in normal humans. J Lipid Res. 1982;23:97-104.

15. Rizzo M, Berneis K. Low-density lipoprotein size and cardiovascular risk assessment. QJM. 2006;99:1-14.

16. Jensen MD, Ryan DH, A CM, et al. 2013 ACC/AHA/TOS guideline for the management of overweight and obesity in adults: a report of the American College of Cardiology/American Heart Association task force on practice guidelines and the Obesity Society. J Am Coll Cardiol. 2014; 63:2985-3023

17. Dansinger M, Williams PT, Superko HR, Asztalos BVF, Schaefer EJ. Effects of weight change on HDL-cholesterol and its subfractions in over 28,000 men and women. J Clin Lipidol. 2019;13(2):308-16 in press.
18. Kaufman HW, Chen Z, Fonseca VA, McPhaul MJ. Surge in newly identified diabetes among medicaid patients in 2014 within medicaid expansion states under the affordable care act. Diabetes Care. 2015;38:833-7.

19. McClure LF, Niles JK, Kaufman HW. Blood Lead levels in young children: US, 2009-2015. J Pediatr. 2016;175:173-81.

20. Kaufman HW, Blatt AJ, Huang X, Odeh MA, Superko HR. Blood cholesterol trends 2001-2011 in the United States: analysis of 105 million patient records. PLoS One. 2013;8:e63416. https://doi.org/10.13 71/journal.pone.0063416.

21. Kroll MH, Bi C, Garber CC, Kaufman HW, Liu D, Caston-Balderrama A, Zhang K, Clarke N, Xie M, Reitz RE, Suffin SC, Holick MF. Temporal relationship between vitamin $\mathrm{D}$ status and parathyroid hormone in the United States. PLoS One. 2015;10:e0118108.

22. Quispe R, Al-Hiji M, Swiger KJ, Martin SS, Elshazly MB, Blaha MJ, Joshi PH, Blumenthal RS, Sniderman AD, Toth PP, Jones SR. Lipid phenotypes at the extremes of high-density lipoprotein cholesterol: the very large database of lipids-9. J Clin Lipidol. 2015;9:511-8.e1-5.

23. Elshazly MB, Quispe R, Michos ED, Sniderman AD, Toth PP, Banach M, Kulkarni KR, Coresh J, Blumenthal RS, Jones SR, Martin SS. Patient-level discordance in population percentiles of the total cholesterol to highdensity lipoprotein cholesterol ratio in comparison with low-density lipoprotein cholesterol and non-high-density lipoprotein cholesterol: the very large database of lipids study (VLDL-2B). Circulation. 2015;132:667-76.

24. Ponda MP, Huang X, Odeh MA, Breslow JL, Kaufman HW. Vitamin D may not improve lipid levels: a serial clinical laboratory data study. Circulation. 2012;126:270-7.

25. Superko HR, Williams PT, Dansinger M, Schaefer E. Trends in LDL-cholesterol blood values between 2012 and 2017 suggest sluggish adoption of the recent 2013 treatment guidelines. Clin Cardiol. 2019;42:101-10.

26. Jago R, Drews KL, Otvos JD, et al. Effect of relative weight group change on nuclear magnetic resonance spectroscopy derived lipopro- tein particle size and concentrations among adolescents. J Pediatr. 2014;164:1091-1098.e3.

27. Hirano $T$, Ito $Y$, Yoshino G. Measurement of small dense low-density lipoprotein particles. J Atheroscler Thromb. 2005;12:67-72.

28. Hirano T, Ito Y, Saegusa H, Yoshino G. A novel and simple method for quantification of small dense low-density lipoprotein. J Lipid Res. 2003; 44:2193-201.

29. Hirano T, Ito Y, Koba S, Toyoda M, Ikejiri A, Saegusa H, Yamazaki J, Yoshino G. Clinical significance of small dense low-density lipoprotein cholesterol levels determined by the simple precipitation method. Arterioscler Thromb Vasc Biol. 2004;24:558-63.

30. Dattilo AM, Kris-Etherton PM. Effects of weight reduction on blood lipids and lipoproteins: a meta-analysis. Am J Clin Nutr. 1992;56:320-8.

31. Lamantia V, Sniderman A, Faraj M. Nutritional management of hyperapoB. Nutr Res Rev. 2016;29:202-33.

32. Björnson E, Adiels M, Taskinen MR, Borén J. Kinetics of plasma triglycerides in abdominal obesity. Curr Opin Lipidol. 2017;28:11-8.

33. Sehayek E, Eisenberg $\mathrm{S}$. Mechanisms of inhibition by apolipoprotein $\mathrm{C}$ of apolipoprotein E-dependent cellular metabolism of human triglyceride-rich lipoproteins through the low density lipoprotein receptor pathway. J Biol Chem. 1991;266:18259-67.

34. Wang CS, McConathy WJ, Kloer HU, Alaupovic P. Modulation of lipoprotein lipase activity by apolipoproteins: effect of apolipoprotein C-III. J Clin Invest. 1985;75:384-90.

35. Berk KA, Yahya R, Verhoeven AJM, Touw J, Leijten FP, van Rossum EF, Wester VL, Lips MA, Pijl H, Timman R, Erhart G, Kronenberg F, Roeters van Lennep JE, Sijbrands EJG, Mulder MT. Effect of diet-induced weight loss on lipoprotein(a) levels in obese individuals with and without type 2 diabetes. Diabetologia. 2017;60:989-97.

36. Chien KL, Lee YT, Sung FC, Su TC, Hsu HC, Lin RS. Lipoprotein(a) level in the population in Taiwan: relationship to socio-demographic and atherosclerotic risk factors. Atherosclerosis. 1999;143:267-73.

37. Vaverková H, Karásek D, Halenka M, Cibíčková L, Kubíčková V. Inverse association of lipoprotein (a) with markers of insulin resistance in dyslipidemicsubjects. Physiol Res. 2017;66(Supplementum 1):S113-20.

38. Sahebkar A, Simental-Mendía LE, Reiner Ž, Kovanen PT, Simental-Mendía M, Bianconi V, Pirro M. Effect of orlistat on plasma lipids and body weight: a systematic review and meta-analysis of 33 randomized controlled trials. Pharmacol Res. 2017;122:53-65. https://doi.org/10.1016/j.phrs.2017.05.022.

39. Diffenderfer MR, Schaefer EJ. The composition and metabolism of large and small LDL. Curr Opin Lipidol. 2014;25:221-6. 
40. Zheng C, Khoo C, Furtado J, Sacks FM. Apolipoprotein C-III and the metabolic basis for hypertriglyceridemia and the dense low-density lipoprotein phenotype. Circulation. 2010;121:1722-34.

41. Brousseau ME, Schaefer EJ, Wolfe ML, et al. Effects of an inhibitor of cholesteryl ester transfer protein on HDL cholesterol. N Engl J Med. 2004;350:1505-15.

42. Bueno NB, de Melo IS, de Oliveira SL, da Rocha Ataide T. Very-lowcarbohydrate ketogenic diet $\mathrm{v}$. low-fat diet for long-term weight loss: a meta-analysis of randomised controlled trials. Br J Nutr. 2013;110:1178-87.

43. Mensink RP, Zock PL, Kester ADM, Katan MB. Effects of dietary fatty acids and carbohydrates on the ratio of serum total to HDL cholesterol and on serum lipids and apolipoproteins: a meta- analysis of 60 controlled trials. Am J Clin Nutr. 2003;77:1146-55.

44. Siri-Tarino PW, Krauss RM. Diet, lipids, and cardiovascular disease. Curr Opin Lipidol. 2016:27:323-8.

45. Hirayama S, Miida T. Small dense LDL: an emerging risk factor for cardiovascular disease. Clin Chim Acta. 2012:414:215-24.

46. Tribble DL, Rizzo M, Chait A, et al. Enhanced oxidative susceptibility and reduced antioxidant content of metabolic precursors of small, dense lowdensity lipoproteins. Am J Med. 2001;110:103-10.

47. Hurt-Camejo E, Camejo G, Rosengren B, et al. Differential uptake of proteoglycan-selected subfractions of low density lipoprotein by human macrophages. J Lipid Res. 1990;31:1387-98.

48. Soran H, Durrington PN. Susceptibility of LDL and its subfractions to glycation. Curr Opin Lipidol. 2011;22:254-61.

49. Younis NN, Soran $\mathrm{H}$, Pemberton $\mathrm{P}$, et al. Small dense LDL is more susceptible to glycation than more buoyant LDL in type 2 diabetes. Clin Sci. 2013;124:343-9.

50. Ai M, Otokozawa S, Asztalos BF, Ito Y, Nakajima K, White CC, Cupples LA, Wilson PW, Schaefer EJ. Small dense LDL cholesterol and coronary heart disease: results from the Framingham offspring study. Clin Chem. 2010;56:967-76.

51. Hoogeveen RC, Gaubatz JW, Sun W, Dodge RC, Crosby JR, Jiang J, Couper D, Virani SS, Kathiresan S, Boerwinkle E, Ballantyne CM. Small dense lowdensity lipoprotein-cholesterol concentrations predict risk for coronary heart disease: the atherosclerosis risk in communities (ARIC) study. Arterioscler Thromb Vasc Biol. 2014:34(5):1069-77.

52. Ostlund RE Jr, Staten M, Kohrt WM, Schultz J, Malley M. The ratio of waistto-hip circumference, plasma insulin level, and glucose intolerance as independent predictors of the HDL2 cholesterol level in older adults. N Engl J Med. 1990;322:229-34.

\section{Publisher's Note}

Springer Nature remains neutral with regard to jurisdictional claims in published maps and institutional affiliations.

Ready to submit your research? Choose BMC and benefit from:

- fast, convenient online submission

- thorough peer review by experienced researchers in your field

- rapid publication on acceptance

- support for research data, including large and complex data types

- gold Open Access which fosters wider collaboration and increased citations

- maximum visibility for your research: over $100 \mathrm{M}$ website views per year

At $\mathrm{BMC}$, research is always in progress.

Learn more biomedcentral.com/submissions 